\title{
CYTOSTATICS AS HAZARDOUS CHEMICALS IN HEALTHCARE WORKERS' ENVIRONMENT
}

\author{
ANNA PAŁASZEWSKA-TKACZ, SŁAWOMIR CZERCZAK, KATARZYNA KONIECZKO, \\ and MALGORZATA KUPCZEWSKA-DOBECKA
}

Nofer Institute of Occupational Medicine, Łódź, Poland

Department of Chemical Safety

\begin{abstract}
Cytostatics not only induce significant side-effects in patients treated oncologically but also pose a threat to the health of occupationally exposed healthcare workers: pharmacists, physicians, nurses and other personnel. Since the 1970s numerous reports from various countries have documented the contamination of working areas with cytostatics and the presence of drugs/metabolites in the urine or blood of healthcare employees, which directly indicates the occurrence of occupational exposure to these drugs. In Poland the significant scale of occupational exposure to cytostatics is also confirmed by the data collected in the central register of occupational carcinogens/mutagens kept by the Nofer Institute of Occupational Medicine. The assessment of occupational exposure to cytostatics and health risks constitutes employers' obligation. Unfortunately, the assessment of occupational risk resulting from exposure to cytostatics raises a number of concerns. Provisions governing the problem of workers' health protection are not unequivocal because they derive from a variety of law areas, especially in a matter of hazard classification and safety data sheets for cytostatics. Moreover, no legally binding occupational exposure limits have been set for cytostatics or their active compounds, and analytical methods for these substances airborne and biological concentrations are lacking. Consequently, the correct assessment of occupational exposure to cytostatics, the evaluation of health hazards and the development of the proper preventive strategy appear difficult. The authors of this article described and discussed the amendments to the European provisions concerning chemicals in the light of employers' obligations in the field of employees' heath protection against the consequences of exposure to cytostatics. Some modifications aimed at a more effective health protection of workers occupationally exposed to cytostatics were also proposed. Int J Occup Med Environ Health. 2019;32(2):141-59
\end{abstract}

Key words:

carcinogenic agents, safety data sheets, healthcare workers, OEL, cytostatic, occupational exposure limits

\section{INTRODUCTION}

Cytostatics constitute a group of chemical substances or mixtures used in cancer chemotherapy. They are toxic for neoplastic cells, and are used for immunosuppression in transplantology and in treatment of some skin or rheumatic diseases of autoimmune character. Due to their mechanism of action, they are divided into several groups. The most commonly used groups of cytostatics include:

- alkylating agents that covalently bind with DNA and RNA forming adducts (cyclophosphamide, ifosfamide, chlorambucil, busulfan, temozolomide, as well as platinum analogues such as cisplatin, carboplatin and oxaliplatin);

- antimetabolites that incorporate into cellular structures and inhibit the synthesis of nucleic acids leading to cell death (methotrexate, fluorouracil, capecitabine, cytarabine, fludarabine, cladribine, gemcitabine, pemetrexed);

- topoisomerase inhibitors that are inserted between the pairs of DNA bases disrupting the nucleic acids func-

Funding: this work was supported by the Nofer Institute of Occupational Medicine (project No. 24.17 entitled "Spatial distribution of occurrence and workers' exposure to the most common occupational carcinogenic or mutagenic factors in Poland," project manager: Katarzyna Konieczko, M.Sc.).

Received: July 31, 2017. Accepted: August 7, 2018.

Corresponding author: Katarzyna Konieczko, Nofer Institute of Occupational Medicine, Department of Chemical Safety, św. Teresy 8, 91-348 Łódź, Poland (e-mail: katarzyna.konieczko@imp.lodz.pl). 
tion or synthesis (topotecan, irinotecan and epipodophyllotoxin derivatives such as etoposide);

- cytotoxic antibiotics disrupting the DNA function or synthesis (anthracyclines such as doxorubicin, epirubicin, bleomycin, mitomycin);

- plant alkaloids and other agents of natural origin usually disrupting the mitotic spindle (vinblastine, vincristine and vinorelbine);

- methylhydrazines (procarbazine) [1,2].

Cytostatic drugs, which have been used in chemotherapy since the 1940s, due to their nonselective mechanism of action, induce significant side-effects in patients treated oncologically. In the 1970s it was found that these drugs might also pose a threat to the health and safety of occupationally exposed pharmaceutical industry and healthcare workers, i.e., pharmacists, physicians, nurses and other personnel [3]. Since then numerous reports from various countries have documented the contamination of working areas with cytostatics and their, or their metabolites, presence in the employees' urine or blood, which directly indicates the occurrence of occupational exposure $[1,4]$.

Processes connected with cytostatics production in their finished state, as well as packaging, distribution, shipment or storage, are the sources of occupational exposure for employees of the pharmaceutical industry. Measurements of cytostatics concentrations in air samples confirmed their presence in the breathing zone of production workers, e.g., during vials filling and methotrexate weighing, their air concentrations reached the maximum values of $0.182 \mathrm{mg} / \mathrm{m}^{3}[5]$; the average exposure level of workers employed in the preparation of cyclophosphamide tablets was $0.0075 \mathrm{mg} / \mathrm{m}^{3}$ [6], and the concentration of $0.34 \mathrm{mg} / \mathrm{m}^{3}$ of $N$-hydroxyurea was measured in the employees' breathing zone at homogenization or granulation of tablet mass and drug encapsulation [7]. Exposure during drug production has concerned a relatively smaller group of employees of pharmaceutical companies, following the requirements of good manufacturing practice (GMP) [8] and restricted exposure control. A significantly wider group of employees who are occupationally exposed to cytostatics consists of healthcare workers responsible for the preparation, administration and storage of this drug, i.e., nurses, medical doctors (MDs) and pharmacy staff, mainly in hospitals. Additionally, those at risk include assisting personnel responsible for cleaning the drug spills and waste disposal, paramedics and roommates handling patient's waste and changing bedclothes, and laundry workers. Moreover, the evolution of veterinary science, the ongoing professional development in this field and the creation of modern veterinary clinics have resulted in the necessity to distinguish veterinary clinics staff as an additional group of workers occupationally exposed to cytostatics. The cytostatics registered for humans are used for veterinary purposes and as such require the proper dose adjustment, e.g., by dilution, weighing, mixing and pouring. The lack of effective protective measures, which are obligatory for healthcare staff in the hospital environment, will put employees of veterinary clinics (veterinarians, students, technicians and cleaning personnel) particularly at risk when exposed to cytostatics used for animals treatment [9]. As far as legal regulations connected with health protection of workers exposed to cytostatics in the European Union (EU) are concerned, specific, mostly national, guidance on safe handling during the preparation, administration and storage of cytostatics exists. It includes the English Health and safety executive (HSE). Safe handling of cytotoxic drug in workplace [10], Control of substances hazardous to health regulations (COSHH). Approved code of practice and guidance (ACOP) [11], the American guidelines published by the American Occupational Safety and Health Administration (OSHA) [12] and the National Institute for Occupational Safety and Health (NIOSH) [13]. Some worldwide guidelines have also been published by the World Health Organization [14]. Many international healthcare institutions (the American Society of Health-System Pharmacists 2006 [15], the International Society of Oncology Pharmacy Practitioners Standards Committee 2007 [16], 
Working Committee on the Safe Handling of Hazardous Drugs 2008 [17], and Oncology Nursing Society 2013 [18]) publish their guidelines and procedures aimed at safe handling of dangerous drugs. However, despite the overallcompliance between existing guidelines, either in the EU or worldwide, there are no harmonized legal regulations specifying the obligations of entities employing healthcare workers in the case of exposure to hazardous drugs, aimed at health protection $[1,19]$.

The EU supports the creation and adoption of minimum standards in safe handling of cytostatics, common for its Member States. In 2016 the European Commission prepared Preventing occupational exposure to cytotoxic and other hazardous drugs 2016. European policy recommendations, in which the development of basic standards concerning regular monitoring of healthcare workers' exposure to cytostatics was declared [20]. Nowadays, the European guidelines for safe handling of cytostatics are described in Standards of practice. Safe handling of cytotoxics published by the International Society of Oncology Pharmacy Practitioners (ISOPP) [16]; however, similar to other guidelines, they are not legally binding.

Moreover, no legally binding occupational exposure limits (OELs) of active compounds of cytostatics have been set for the working environment air or for biological material, and cytostatics airborne and biological concentration monitoring methods are lacking. No cytogenetic surveillance of exposed workers occurs. The afore-mentioned issues impede the proper occupational exposure assessment, the results of which are the basis for employers in the selection of the appropriate and effective preventive measures. On the other hand, technological progress in the analytical methodology of measuring chemical substances in different media enables reliable measurements of very low concentrations.

As cytostatics are chemical mixtures, it is also essential to mention that in 2006 the European legislation concerning chemicals was significantly amended. Regulation (EC) No 1907/2006 of the European Parliament and of the Council of 18 December 2006 concerning the registration, evaluation, authorization and restriction of chemicals (REACH) [21] came into force to control the trade in chemical substances and mixtures, which influenced the majority of enterprises within the European Economic Area (EEA). In 2009 the legal approach to the classification connected with hazards and labeling of chemicals was also transformed and amended. The suppliers are now obliged to label the substance or mixture in the packaging in accordance with Regulation (EC) No 1272/2008 of the European Parliament and of the Council of 16 December 2008 on classification, labelling and packaging of substances and mixtures (CLP) [22], before placing it in the market. The current legislation in the field of chemicals is ambiguous when it comes to both the classification of cytostatics for the hazards posed and the preparation of safety data sheets (SDSs) for them.

The primary goal of the article is to analyze the employers' obligations resulting from the EU legislation concerning chemicals, and especially regulations on the risk assessment connected with occupational exposure to cytostatics. Furthermore, the authors aim to raise the awareness of medical staff, and occupational safety and health (OSH) specialists in the healthcare sector, that they need to be compliant not only with the regulations concerning medicinal products and medical devices, but also with the requirements arising from legislation on chemicals.

\section{METHODS}

The structured literature review was performed with the use of factographic and bibliographic databases of peerreviewed journals (Web of Science, Ebsco, Medline). Due to the wide scope of the discussed problem, the main focus was on the latest scientific publications. The authors took into consideration articles on occupational exposure to cytostatics, and in particular data concerning health effects, SDSs of the leading manufacturers of cytostatics and documentations on occupational exposure limit values (OELV) for methotrexate, cyclophosphamide, cis- 
platin and hydroxyurea. The EU legal instruments on the assessment of occupational exposure to cytostatics were analyzed on the basis of the latest legislative notes and regulations available on the EUR-Lex platform.

\section{RESULTS}

\section{Toxicity and occupational exposure to cytostatic drugs}

Toxicity of cytostatics among oncologically treated patients has been well documented. As it is usually the case with nonselective drugs in their mode of action, cytostatics cause a number of serious side-effects including hepatic and renal damage, toxicity to the cardiovascular system, the respiratory track, the immune system, the nervous system, skin and other [23]. While in patients cytostatics are administered mostly intravenously or orally, when it comes to occupational conditions, skin is the main route of exposure. Skin contact with a drug occurs when preparing injection solutions, opening ampoules and vials, filling and venting syringes, needle-stick or broken vials injuries and touching contaminated surfaces (tables, cabinets, tools, floor, handles, phones, etc.), contact with oncological patients' bedding, clothes and biological material, and also when cleaning patients' waste and drug spills. The direct evidence for skin absorption is the presence of cytostatics, or their metabolites, in biological material samples (exhaled air, body fluids, tissues) of the exposed person.

Since 1996 the presence of a number of cytostatics (cyclophosphamide, methotrexate, ifosfamide, epirubicin, cisplatin, carboplatin) or their metabolites in the urine of medical staff (nurses, pharmacists, MDs) has been evidenced in numerous studies described in over 60 publications [2432]. In 1 of the studies conducted in 4 Polish hospitals, the cytostatics contamination of the working environment at drug preparation and administration was assessed [26]. At the oncological wards of all hospitals, at least 1 out of 8 assessed drugs was identified (cyclophosphamide, methotrexate, ifosfamide, docetaxel, etoposide, 5-fluorouracil, gemcitabine, paclitaxel). The highest concentration of the analyzed drugs was described in wipes collected from the floor under the infusion stand. In 2 hospitals, the maximum concentrations were $75 \mathrm{ng} / \mathrm{cm}^{2}$ and $59 \mathrm{ng} / \mathrm{cm}^{2}$ - several hundred times exceeding the German standard value equaling $0.1 \mathrm{ng} / \mathrm{cm}^{2}$, cited by the authors [26]. On other contaminated surfaces, the maximum concentrations were measured in the case of fluorouracil $\left(6.1 \mathrm{ng} / \mathrm{cm}^{2}\right.$ on the patient's chair's backrest) and ifosfamide $\left(2.5 \mathrm{ng} / \mathrm{cm}^{2}\right.$ on the phone handset). In the urine of the personnel preparing and administering cytostatics, the maximum concentration of cyclophosphamide was $500 \mathrm{ng} / 24 \mathrm{~h}$ (MD), $492 \mathrm{ng} / 24 \mathrm{~h}$ (nurse) and $358 \mathrm{ng} / 24 \mathrm{~h}$ (pharmacist) [27].

The absorption of cytostatics by inhalation among medical personnel cannot be excluded either [29,33-36]. The absorption of a drug is possible by direct inhalation of drug aerosols formed during normal handling, as a result of the hypertension generated during drug preparation and administration, or direct inhalation of drug dust arising during tablets crushing, and also due to secondary contamination of the working surfaces, clothes and containers. Exposure to cytostatics vapor released when moving the drug from one container to another is also possible. The most reliable data from occupational monitoring of cytostatics air concentrations was found for cyclophosphamide. The maximum concentrations measured under the hood were $0.010-0.013 \mathrm{mg} / \mathrm{m}^{3}$ [36-38], in drug administration rooms $-0.5 \times 10^{-6}-0.2 \times 10^{-5} \mathrm{mg} / \mathrm{m}^{3}[25]$, and in the hospital laundry $-0.39 \times 10^{-6}-12.7 \times 10^{-6} \mathrm{mg} / \mathrm{m}^{3}$ [39]. In the preparation room at a Dutch hospital ward, methotrexate was detected in the concentration of $0.0003 \mathrm{mg} / \mathrm{m}^{3}$ [40]. The cytostatics exposure effects described in the literature concern mostly the hospital pharmacy personnel exposed during drug preparation, mixing and intravenous infusions preparation. A small but statistically significant, increase in such symptoms as diarrhea and chronic sore throat among pharmacists and pharmacy technicians $(\mathrm{N}=738)$ was documented in comparison to the control [41]. Moreover, headaches and dizziness, hair loss, nausea and vom- 
iting, rashes and general hypersensitivity among medical personnel were reported [42-44].

The results of the study conducted among nurses handling cytostatics for several years indicate that these drugs may lead to liver injury (irreversible hepatic fibrosis) [45]. The medical and nursing personnel of chemotherapy wards handling cytostatics in Polish hospitals reported such exposure effects as lachrymation, conjunctival dryness, redness and itching of the eyes (47\%), skin irritation (44\%), mucous membranes irritation (39\%), increased eyebrows and eyelashes loss (30\%), experienced heart rhythm disorders (16\%), and nausea and vomiting (8\%) [32,46]. Oncology patients care assistants, just after emptying commodes with the urine of vincristine and adriamycin patients, developed allergic reactions in the form of a pruritic, disseminated rash on the face, neck, torso and arms [47]. Immune system disorders connected with a statistically significant increase in $\mathrm{IgG}, \mathrm{IgA}$ and $\mathrm{IgM}$, in comparison to the general population, were observed in the case of 53 scientists working on the new formulations of cytostatics [48].

Positive results of cytogenetic studies, to the extent of the chromosomal aberrations analysis (peripheral lymphocytes), sister chromatid exchanges observations, micronucleus tests, the comet assay and the gene mutations assay, were described in respect of medical personnel, especially nurses exposed to different cytostatics (cisplatin, cyclophosphamide, ifosfamide, vincristine, doxorubicin, dactinomycin, cytosine, methotrexate). The case-control studies conducted among oncology nurses showed the relationship between the incidence of miscarriages and exposure to cytostatics that was statistically significant in the first trimester. The risk of miscarriage of the medical personnel was 2-3.5 times higher in comparison with the control. An increased risk of impaired fertility $(\mathrm{OR}=1.42$ $1.5)$ and premature birth $(\mathrm{OR}=5.56)$ was also observed in the case of the exposed personnel.

The exposure in question resulted in numerous malformations of the fetus - malformations of the limbs and cleft palate, as well as learning difficulties of the offspring in further years $(\mathrm{OR}=2.56)[29,32,49-57]$. In the studies of nurses and pharmacists exposed to cytostatics, the chromosomal changes specific for the myelodysplastic syndrome and acute myeloblastic leukemia were detected. Moreover, the incidence of leukemia among exposed nurses was 10 times higher, and the incidence of non-Hodgkin lymphoma among pharmacy technicians - 3.7 times higher, than in the control [29]. For the last 15 years, in the Department of Pediatric Bone Marrow Transplantation, Oncology and Hematology of the Wroclaw Medical University, among 100 people employed (20 MDs and 80 nurses) and exposed to cytostatics, 9 cases of malignant tumors have been described as potentially resulting from occupational exposure [58]. The authors of the report in question point out that, in the described department, MDs are the most affected group (5 cases). The most commonly used cytostatics in the clinic are methotrexate, cyclophosphamide, ifosfamide, cytarabine, busulfan and ciclosporinum.

\section{Occupational exposure to cytostatics in Poland}

Nowadays, in Poland the chemical substances, whether on their own or in mixtures, that meet the CLP Regulation classification criteria as carcinogenic or mutagenic category $1 \mathrm{~A}$ or $1 \mathrm{~B}$, are regarded as occupational carcinogens or mutagens. The current Polish regulation including the inventory of occupational carcinogens or mutagens [59] is in compliance with the CLP Regulation. Moreover, this regulation includes a number of obligations for the employers whose workers are exposed to occupational carcinogens or mutagens. One of these is the obligation to register and keep records on exposure occurrence and the number of workers exposed.

According to the reference provisions, a chemical substance is carcinogenic when it induces cancer or increases the incidence of cancer. The substance is classified into category 1 when it is a known or presumed human carcinogen, on the basis of epidemiological and/or animal data. A further allo- 
cation of the substance into category $1 \mathrm{~A}$ or $1 \mathrm{~B}$ depends on the strength and weight of carcinogenicity evidence. Most often, substances are classified as Carc. 1A when they have a carcinogenic potential for humans mainly due to human evidence, and as Carc. 1B when they are presumed to have a carcinogenic potential for humans mainly due to experimental animals evidence [22,59].

The germ cell mutagenicity hazard class is concerned with chemicals which may cause mutations in the humans' germ cells that may be transmitted to the progeny. Similar to carcinogens, substances known to be, or regarded as being, heritable in the germ cells of humans are classified into category 1 and then, on the basis of the available scientific evidence, allocated to category $1 \mathrm{~A}$ or $1 \mathrm{~B}$.

Chemical mixtures are classified as carcinogenic or mutagenic, depending on the content of the substance classified into either of the hazard classes described above.

As it was already mentioned, in accordance with the Polish regulation concerning occupational carcinogens, the chemical substances, whether on their own or in mixtures, that meet the CLP classification criteria as carcinogenic or mutagenic category $1 \mathrm{~A}$ or $1 \mathrm{~B}$ are regarded to be occupational carcinogens or mutagens no matter if they have or do not have a harmonized classification [59]. The ultimate responsibility to classify the substance rests with its manufacturer or importer.

In the opinion of many manufacturers, the number of cytostatic drugs (cisplatin, cyclophosphamide, doxorubicin, cyclosporin, azathioprine, melphalan and others) meet the CLP classification criteria as carcinogenic or mutagenic category $1 \mathrm{~A}$ or $1 \mathrm{~B}$ and as such should be regarded as occupational carcinogens or mutagens. It is important to note that a chemical substance without any harmonized classification may be classified differently by various manufacturers. This is the reason why users should take into consideration the substance classification of their direct supplier, and any doubts should be clarified within the same supply chain specific for this substance.
Apart from the EU classification criteria for carcinogenicity (CLP), the occupational cancer assessment is also very often based on the reliable data gathered and published by the International Agency for Research on Cancer (IARC). So far the Agency has classified 31 active components of cytostatics in diverse carcinogenicity groups - 9 into IARC group 1 "Carcinogenic to humans," 8 into IARC group 2A "Probably carcinogenic to humans," and 8 into IARC group 2B "Possibly carcinogenic to humans." The International Agency for Research on Cancer classification is not legally binding but is appreciated by scientists. Challenging for employers and OSH specialists is the fact that none of those 25 active components of cytostatics, classified by IARC into group 1 or 2 [60] has the EU harmonized classification as carcinogenic or mutagenic under the CLP Regulation. Any manufacturer or importer who places such substances in the market is legally obliged to notify the European Chemicals Agency (ECHA) of the classification and labeling to be included in the classification and labeling inventory ( $\mathrm{C} \& \mathrm{~L}$ Inventory). This obligation applies to all substances, whether on their own or in mixtures, meeting the classification criteria as hazardous regardless of the quantities that are placed in the EU market.

The database developed on the basis of the provided information (C\&L Inventory) is made available and updated by ECHA. It includes information on the classification and labeling of notified and registered substances, received from manufacturers and importers, and also contains a list of harmonized classifications. However, it is important to distinguish the legally binding harmonized classification from other information included in the C\&L Inventory, declared by individual manufacturers or importers. The declared information is not legally binding and has not been verified by the ECHA experts; moreover, the same substance may be classified differently by various notifiers if it does not have a harmonized classification. ECHA does not guarantee the correctness of the information included in the C\&L Inventory, and the 
REACH Regulation does not allow it to modify the data sent by the information owner (manufacturer of importer of the substance).

However, information from the database may be useful at the initial stage of hazards identification, but in every particular case the information provided by the supplier in the specific supply chain should be taken into consideration. Among the 9 substances classified by the IARC into group 1 , all except chlornaphazine were notified to the $\mathrm{C} \& \mathrm{~L}$ Inventory as meeting the classification criteria for carcinogenic or mutagenic category $1 \mathrm{~A}$ or $1 \mathrm{~B}$ under the CLP Regulation. The highest number of notifications was reported for cyclosporin (132), azathioprine (70) and melphalan (65).

In Poland the Nofer Institute of Occupational Medicine (NIOM) keeps the Central Register of Data on Exposure to Carcinogenic or Mutagenic Substances, Mixtures, Agents or Technological Processes in which data on occupational exposure to carcinogens or mutagens in Poland has been collected since 1999 [61]. Before Poland's accession to the EU in 2004, the information collected in the central register had included data on exposure to substances classified as occupational carcinogens by IARC. By 2004 occupational exposure to 7 cytostatics from IARC group 1 had been reported, i.e., azathioprine, busulfan, chlorambucil, cyclophosphamide, cyclosporin, chlornaphazine, melphalan and cisplatin. In 2004, together with adjusting the provisions concerning chemicals to the EU regulations, the above cytostatics were excluded from the legally binding Polish list of occupational carcinogens, which was replaced by a new inventory of carcinogenic or mutagenic substances with the official EU classification as such. In 2012 the inventory of occupational carcinogens or mutagens was removed, and a reference to the classification of the substance in accordance with the CLP Regulation was introduced. Currently, NIOM is trying to recollect the reports on exposure to cytostatics for the period 2013-2016, but such data is not complete because of the legal gap that occurred between 2004 and 2012, and the employers' need to adapt to the current legal situation in this area.

In Poland both employers and the sanitary inspection find it especially difficult to identify cytostatics that should be regarded as occupational carcinogens (Carc./Muta. category $1 \mathrm{~A}$ or $1 \mathrm{~B}$ ) and reported to the central register. On the one hand, there is a harmonized classification established for these substances. On the other hand, suppliers very often fail to provide SDSs because they consider their products to be medicines in the finished state, intended for the final user, and as such not subject to the REACH and CLP Regulations. As it was already mentioned, the classifications of cytostatics notified to the ECHA C\&L Inventory by manufacturers or importers were not verified by the Agency and may have differed among various notifiers. That is why it is so important to establish the classification of cytostatics in the specific supply chain. Furthermore, there are some cytostatics not meeting the CLP carcinogenicity criteria but, according to their manufacturers, the data confirming their mutagenic potential is sufficient to classify them as such, e.g., methotrexate classified by many notifiers as Muta. 1B or even 1A should also be reported to the central register as occupational carcinogens.

In 2013 data concerning occupational exposure to cytostatics in Poland was reported only from 4 enterprises ( 2 hospitals and 2 research institutes) about 6 substances. In 2016 reports included data on 28 active components of cytostatics classified as Carc. 1A or 1B from 44 enterprises - mostly hospitals (> 60\%). Similar to the period 19992004, the majority of exposed employees were women ( $>90 \%$ ), but there was a significant decrease in the proportion of women $<45$ years old to the total number of women exposed, from $>70 \%$ in 1999-2004 to about 44\% in recent years. Figures 1 and 2 present 4 cytostatics reported to the central register most often in 2013-2016, with no harmonized classification, but meeting the CLP classification criteria as carcinogenic or mutagenic category 1 . There is a gradual increase in both the number of 


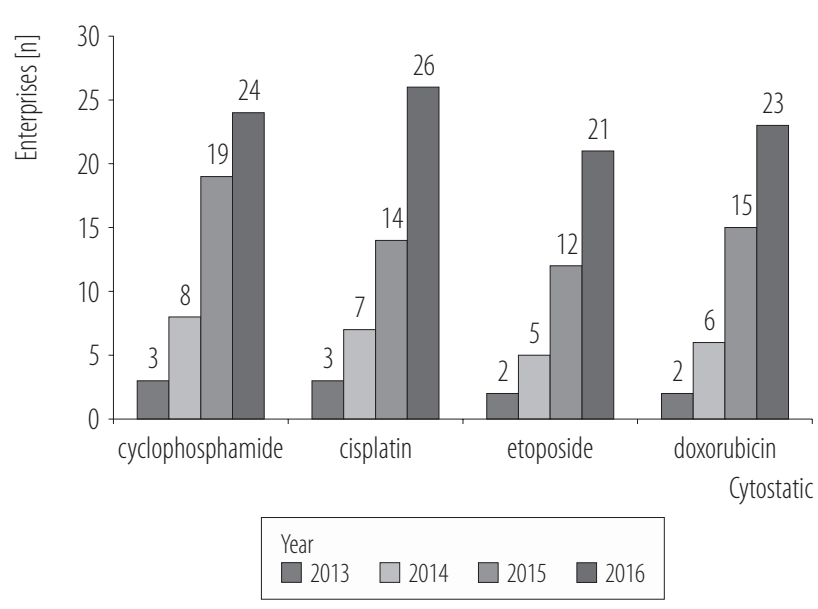

Figure 1. Enterprises reporting exposure to the most common cytostatics to the Central Register of Data on Exposure to Carcinogenic or Mutagenic Substances, Mixtures, Agents or Technological Processes in Poland in 2013-2016 [61]

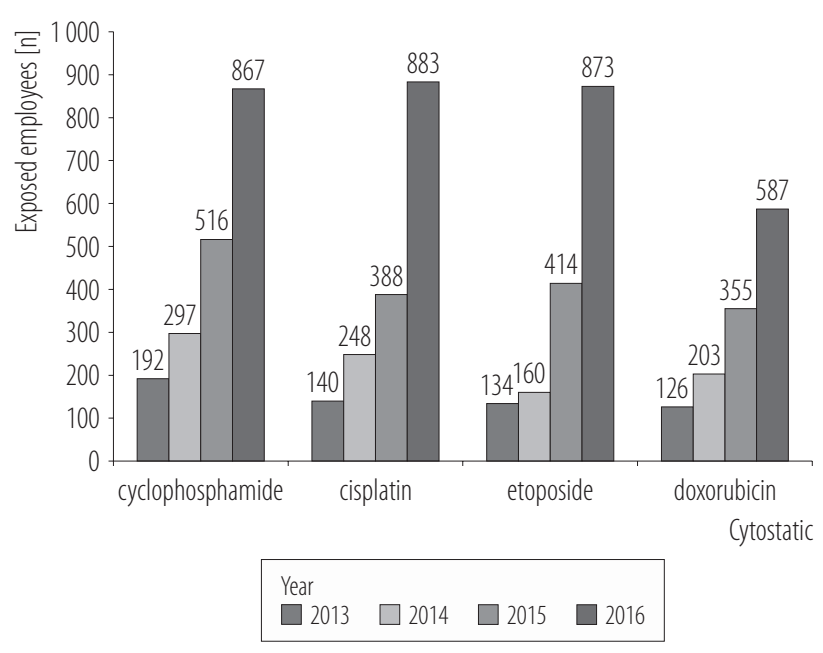

Figure 2. Employees exposed to the most common cytostatics reported to the Central Register of Data on Exposure to Carcinogenic or Mutagenic Substances, Mixtures, Agents or Technological Processes in Poland in 2013-2016 [61]

enterprises reporting the exposure to cytostatics and the number of employees exposed [56].

According to the data gathered and reported by the sanitary inspection, in 2010 in 1776 healthcare facilities in Poland (i.e., $34.7 \%$ of the total number of registered facilities) among 290937 employees, 3220 (including 2956 females) were occupationally exposed to cytostatics [62].

\section{Employers' obligations}

in the field of employees health protection against the consequences of exposure to cytostatics

The legislation on the safety and health of employees using chemical substances exists in all Member States. There is usually some kind of a framework provision concerning safety and health at work, supplemented by other more specific requirements connected with chemicals. The existing national regulations transpose the EU Council Directive of 12 June 1989 on the introduction of measures to encourage improvements in the safety and health of workers at work (89/391/EEC with the latest consolidated version of 2008) [63] and other directives related to the protection of workers from the risks related to exposure to hazardous agents including chemicals (i.a., 98/24/EEC, 2004/37/WE) $[64,65]$. Moreover, there are 2 Regulations (EC) concerning chemicals, binding directly in all EU countries REACH (Regulation (EC) No 1907/2006) [21] and CLP (Regulation (EC) No 1272/2008) [22], which are also connected with workers' health protection.

What is common for all those provisions is the fact that employers are responsible for the management of risk connected with working conditions. They are obliged to prepare a detailed risk assessment and take the required prevention and protection measures based on the results obtained during this risk assessment. Employees have to be fully informed on the health risk resulting from their work, including exposure to hazardous chemicals, as well as instructed on how to minimize the potential hazards and provided with effective personal protective equipment (PPE). When it comes to chemicals, occupational risk is the probability of potential health damage resulting from exposure to a hazardous chemical agent present in the workplace. A hazardous chemical substance or mixture is a chemical agent that meets the classification criteria into at least 1 physical, health or environmental hazard class defined in the CLP Regulation, whether it has the harmonized CLP classification or not, or any other 
chemical agent not meeting the reference criteria, which may pose a safety and health risk to workers, due to its physicochemical properties or health impact, and the way it is used in the working environment. These are usually chemical agents or dusts with OELV, but it should be emphasized that occupational risk assessment is obligatory not only for chemicals with OELs but for all chemicals present in the working environment. In such a situation, the risk should be evaluated qualitatively with the use of a simple estimation methodology, such as the risk score or other matrix methods that are usually proposed in national standards for risk evaluation.

\section{Classification and labeling of cytostatic drugs}

as hazardous chemicals

Currently, information about hazards posed by chemicals is clearly communicated to employees and consumers in the EU by means of their classification and labeling in accordance with the criteria set out in the CLP Regulation [22]. The Regulation, as a general principle, applies to all chemical substances and mixtures supplied in the Community, except for those for which the remaining Community legislation lays down more specific rules and procedures on placing them in the market, in the context of safety requirements. The classification labelling and packaging of substances and mixtures shall not apply to chemicals in the form of medicinal products as defined in Directive 2001/83/EC of 6 November 2001 on the community code relating to medicinal products for human use [66], which are in the finished state, intended for the final user. According to the definition included in Article 1 point 2 of this Directive, a medicinal product is:

- any substance or combination of substances presented as having properties for treating or preventing disease in human beings; or

- any substance or combination of substances which may be used in or administered to human beings, either with a view to restoring, correcting or modifying physiologi- cal functions by exerting a pharmacological, immunological or metabolic action, or to making a medical diagnosis.

However, pursuant to Article 3 of the Directive [66], the following products are excluded from its scope:

- Any medicinal product prepared in a pharmacy in accordance with a medical prescription for an individual patient (commonly known as the magistral formula).

- Any medicinal product which is prepared in a pharmacy in accordance with the prescriptions of a pharmacopoeia and is intended to be supplied directly to the patients served by the pharmacy in question (commonly known as the officinal formula).

- Medicinal products intended for research and development trials.

- Intermediate products intended for further processing by an authorized manufacturer.

At the same time, neither the CLP Regulation [22] nor Directive 2001/83/EC [66] precisely defines the final user. According to ECHA, the interpretation of this issue was agreed with the national REACH and CLP Helpdesks, and published on the ECHA website [67]. The European Chemicals Agency experts explain that, "Substances and mixtures which are in the finished state and intended for the final user, and which are medicinal products within the scope of Directive 2001/83/EC on the Community code for medicinal products for human use, or veterinary medicinal products within the scope of Directive 2001/82/EC on the Community code relating to veterinary medicinal products, are on the whole exempted from the provisions of the CLP Regulation, i.e., they do not have to be classified, packaged, labelled and notified to the C\&L Inventory. However, in cases where a manufacturer or importer supplies substances and mixtures, e.g., active pharmaceutical ingredients (APIs) or excipients, that are not yet in the finished state, this manufacturer or importer will have to classify, package and label these substances and mixtures in accordance with the CLP. In addition, if these sub- 
stances are placed in the market, they will also have to be notified to the C\&L Inventory. The exemption from the provisions of the CLP Regulation does not distinguish between active and non-active pharmaceutical ingredients: it applies to any substance or mixture used in medicinal products, e.g., excipients, which is in the finished state and intended for pharmaceutical use." [67].

Furthermore, ECHA highlights that "the finished state of the medicinal product relates to the substance or mixture and not to its package since re-packing the tablets does not alter the substance/mixture. Bulk tablets that will not be altered after having been produced are therefore considered in the finished state intended for the final user." [67] At the same time, ECHA advises to protect the health of workers who have contact with bulk tablets, by ensuring safe handling, with the appropriate safe use instructions, during transferring and packaging stages, until they reach the final user in the appropriate package [67].

In the authors' opinion, ECHA's position should be verified in the light of the finished medicinal product descriptions included in Directive 2001/83/EC, the WHO's guidelines [68] and the European Medicines Agency's (EMA) guidelines concerning GMP [8]. According to them, the finished medicinal product should be understood as the product that has undergone all stages of production, including packaging in its final container and labeling released to the EU market, after certifying the batch by a qualified person (QP) of the importer. It seems that only the medicine in the retail package for the end-user should be considered consistent with the definition of a finished product.

The available literature-related data confirms that a measurable concentration of cytostatics is also present on the outer surface of the package. Monitoring of the total amount of cyclophosphamide on the primary vials with the drug ranging 6.5-28 $\mathrm{ng}$ in the case of $200 \mathrm{mg}$ vials, and 10-216 ng in the case of $1000 \mathrm{mg}$ vials [69]. As a consequence of cytostatics manipulation, the drugs were detected on different working surfaces, tablets counting trays, ventilation hoods, refrigerators and safety cabinets in over 100 different studies conducted after 1994 [29]. The International Society of Oncology Pharmacy Practitioners [16] recommends that cytostatics in the finished state are readily recognizable for the personnel involved in their handling. The outer packaging of cytostatics containers should have a proper label and display clear warning, e.g., "Danger/Caution Cytotoxics."

In summary, all the cytostatics that do not fall within the scope of Directive 2001/83/EC [60], i.e., they are not finished products, intended for end-users, should be classified and labeled in accordance with the CLP Regulation. Active pharmaceutical ingredients in the form of raw materials and mixtures, prepared as solutions, e.g., by dilution or dissolving, should be classified and labeled in accordance with the CLP Regulation if they meet the classification criteria. In most cases, manufacturers or importers are obliged to decide on the classification of their chemical substances or mixtures by themselves - auto-classification. Under the CLP Regulation [22], the mixtures' classification should be based on:

- experimental data concerning the mixture or its components gathered in tests for physical hazards, as well as toxicological and ecotoxicological tests,

- data from epidemiological studies, historical human data, such as records from industry, or data from poisoning centers,

- data generated in validated qualitative and quantitative models, such as (Quantitative) the Structure Activity Relationships ((Q)SAR), appropriate in vitro tests, "read across" or category approaches,

- data gathered as a result of scientific literature review. When the data listed above is not available, the bridging principles or calculation methods need to be used for the purposes of chemical mixture classification. When the chemical substance or mixture is classified as hazardous, the supplier is obliged to label the substance or mixture in accordance with the CLP Regulation before placing it in the market. 
Safety data sheet for cytostatic drug?

Pursuant to Title IV, Article 31 of the REACH Regulation [21], the supplier of chemical substances or mixtures that meet the criteria for classification as hazardous in accordance with the CLP Regulation shall provide the recipient with safety data sheets. For manufacturers and importers of chemicals, the SDS is the main tool assuring the sufficient information in the supply chain that enables the safe use of their chemical substance or mixture.

Safety data sheets contain information on the properties of the substances or mixtures, associated hazards and handling instructions, disposal procedures and transport, as well as first aid measures, firefighting measures and exposure controls. The safety data sheet format needs to be compliant with Annex II of the REACH Regulation [21]. Title IV covers the requirements for safety data sheets, including the obligation to provide information down the supply chain for substances on their own or in mixtures, for which a safety data sheet is not required, the obligation to provide information on substances and mixtures up the supply chain and define the access to information for workers, and the obligation to retain such information. Employee training and access to SDSs are legally required but the way how this is to be done is not specified in the Regulation. Placing the paper version of SDSs in the binder, or the electronic version of SDSs in the virtual directory, and keeping the log with the employees' signatures affixed after reading the SDS, seem to be the best practice. The REACH Title IV provisions shall not apply to the substances used in medicinal products for human use, defined in Directive 2001/83/EC [66]. It means that the SDS is not required for medicinal products which are in the finished state, despite the fact that, according to the toxicological data, they may be hazardous to human health or life. Handling the medicinal products in their finished state requires strictly controlled conditions that will assure safe administration to the patient with the lowest possible risk to healthcare professionals.
As far as cytostatics are concerned, the SDS should be made for every cytostatics that was classified and labeled in accordance with the CLP Regulation, mainly for active substances/components on their own and in mixtures, in the form of cytostatics solutions prepared by dilution or dissolving for individual needs.

It should be noted that the SDSs for the same substance provided by various manufacturers may vary and such cases constitute a problem for the employer, as it may be necessary to use other risk management measures and personal protective equipment after changing the supplier of the substance used for the recipe.

In the U.S. there is a legal obligation to provide the recipient with SDS for hazardous medicinal products also in the finished state, to protect not only pharmacists but also assisting personnel. The U.S. National Institute of Occupational Safety and Health publishes the lists of hazardous drugs for which the SDSs are required [70]. The definition of hazardous drugs developed by the American Society of Health-System Pharmacists (ASHP) [15] and revised by NIOSH [13] covers the drugs containing at least 1 of the following 6 characteristics in respect of humans or animals:

- carcinogenicity,

- teratogenicity or other developmental toxicity,

- reproductive toxicity,

- organ toxicity at low doses,

- genotoxicity,

- structure and toxicity profiles of new drugs that mimic existing drugs determined to be hazardous under the above criteria.

\section{Monitoring of cytostatics concentrations}

in the working environment and hygiene standards (OELVs)

The mode and frequency of chemical concentration measurements are governed in detail by the national legislation of Member States, and usually depend on the classification of the chemical substance and the results obtained 
in recent measurements. In Poland, when the chemical substance or dust hazardous to health (except for carcinogenic and mutagenic agents) is present in the working environment, there is an obligation to measure its concentration every 2 years when the last measured concentration is $0.1-0.5$ of the Polish OELV, or annually when the last measured concentration is $>0.5$ of the Polish OEL. If the chemical substance is classified as carcinogenic or mutagenic, the measurements of its airborne concentrations need to be done every 6 months when the last measured concentration is $0.1-0.5$ of the Polish OELV, or every 3 months when the last measured concentration is $>0.5$ of the Polish OELV [71].

Effective monitoring of particular cytostatics concentrations in occupational conditions requires the use of selective analytical methods of determining those substances at the workplaces, including worker's exposure to dusts generated during the manipulation of a drug in the form of tablets as well as exposure to aerosols of liquid drugs. Exposure to vapor cannot also be excluded in the case of some cytostatics, e.g., cyclophosphamide (vapor pressure: $5.93 \times 10^{-5} \mathrm{hPa}\left[25^{\circ} \mathrm{C}\right]$ ) or cisplatin (vapor pressure: $1.8 \times 10^{-5} \mathrm{hPa}\left[20^{\circ} \mathrm{C}\right]$ ) [36]. Recently in Poland, as part of the work of the Interdepartmental Commission for Maximum Admissible Concentrations and Intensities for Agents Harmful to Health in the Working Environment (an administrative body under the Polish Minister of Family, Labor and Social Policy), the selective analytical methods of determining methotrexate, cisplatin, cyclophosphamide and hydroxyurea in the air of working environment have been developed and published. In the developed methods, the measuring ranges have been as follows:

- for cisplatin: $0.00018-0.0625 \mathrm{mg} / \mathrm{m}^{3}$ when collecting $960 \mathrm{l}$ of air, and $0.00025-0.0833 \mathrm{mg} / \mathrm{m}^{3}$ when collecting 7201 of air [72];

- for methotrexate: $0.00007-0.0028 \mathrm{mg} / \mathrm{m}^{3}$ [73];

- for cyclophosphamide: $0.0004 \mathrm{mg} / \mathrm{m}^{3}$ [74];

- for hydroxyurea: $0.001 \mathrm{mg} / \mathrm{m}^{3}$ [75].
However, developing the appropriate and effective analytical methods of determining cytostatics in the air at the workplaces is not sufficient for the full assessment of the working environment in terms of worker's health risks. There is no possibility to effectively monitor occupational exposure to cytostatics because neither the EU directives nor the Polish legislation have established the legally binding levels of the OELs for those chemicals.

The key manufacturers and importers of active components of cytostatics recommend the admissible levels of airborne concentrations at workplaces in their SDS, but these values are not legally binding and no scientific basis or criteria for setting them are available. This is the reason why in 2015-2016 the Polish Group of Experts for Chemical Agents (GECA), acting within the framework of the Interdepartmental Commission for Maximum Admissible Concentrations and Intensities for Agents Harmful to Health in the Working Environment, started to work on scientific recommendations to underpin regulatory proposals on OELVs for cytostatics. Monographs for 4 cytostatics with the recommended OELVs given in brackets were prepared - methotrexate $\left(0.001 \mathrm{mg} / \mathrm{m}^{3}\right.$, inhalable fraction), cyclophosphamide $\left(0.01 \mathrm{mg} / \mathrm{m}^{3}\right)$, cisplatin $\left(0.002 \mathrm{mg} / \mathrm{m}^{3}\right)$ and hydroxyurea $\left(0.1 \mathrm{mg} / \mathrm{m}^{3}\right)$ [76-79]. Currently, there is ongoing legislative work to introduce the proposed reference values (OELVs) to the Polish list of legally binding OELs.

Moreover, the effective monitoring of occupational exposure to cytostatics could be conducted by examining the cytogenetic and mutagenic effects as an indicator of DNA damage among exposed subjects [32]. Most of cytostatics actively bind DNA, inducing genotoxic effects. Villarini et al. (2016) [4] prepared a meta-analysis of 24 studies published in 1988-2015, concerning the micronuclei $(\mathrm{MN})$ creation in peripheral blood lymphocytes of healthcare employees occupationally exposed to cytostatics. The authors confirmed an association between occupational exposure to cytostatics and cytogenetic effects 
with an overall metaestimate of 1.67 (95\% CI: 1.41-1.98) as in $62.5 \%$ of the analyzed studies, the frequency of $\mathrm{MN}$ in exposed workers was increased in comparison to the control. In $66.6 \%$ of the studies, at least 1 other genotoxicity biomarker, besides the micronuclei assay, was used for monitoring the biological effects (sister chromatid exchanges, chromosome aberrations or comet assay for primary DNA damage). The outcomes of other genotoxicity tests used and the micronuclei assay were coherent.

\section{CONCLUSIONS}

Side-effects among cancer patients treated with cytostatics are serious and numerous. Data published in the scientific literature suggests that these may also pose a threat to the health and life of hospital staff taking care of cancer patients, i.e., pharmacists, MDs, nurses and supporting staff exposed in the occupational conditions. In order to meet the increasing challenges connected with healthcare professionals' exposure to cytotoxic substances during the preparation or administration of cytotoxic drugs, and their health or life consequences, greater attention should be paid to the risk assessment of occupational exposure to these substances.

Many doubts have arisen around the problem of risk assessment connected with occupational exposure to cytostatics. Both in the EU and Poland, legal regulations concerning issues connected with health protection of workers occupationally exposed to cytostatics derive from different legal areas and are not unequivocal. In the article, the authors' opinion, from the legal point of view, is that patients are the final users of cytostatics - and for them these are the products in the finished state.

All cytostatics that do not fall under the provisions of Directive 2001/83/EC, and are not in the finished state, intended for the final user, shall be classified and labeled for the health and environmental hazards they pose. As it was already mentioned, active components of cytostatics in the form of raw materials and mixtures, prepared as cy- tostatics solutions, e.g., by dilution or dissolving, should be classified and labeled according to the CLP Regulation if they meet the classification criteria. Cytostatics manufacturers and importers are obliged to classify their products by themselves as these substances have no harmonized legally binding classification. Additionally, in Poland in the case of cytostatics that meet the CLP Regulation classification criteria as carcinogenic or mutagenic category $1 \mathrm{~A}$ or $1 \mathrm{~B}$, employers are legally obliged to keep registers of those agents occurrence in their enterprises and registers of the employees occupationally exposed, and to report the exposure data to inspection services.

Safety data sheets shall be prepared for all cytostatics that have been classified and labeled according to the CLP Regulation criteria [22]. For medicinal products in their finished state, there is no obligation to prepare a SDS, despite the fact that, according to latest toxicological data, they may pose a significant risk to health.

In 2013-2015, according to the data reported to the Central Register of Data on Exposure to Carcinogenic or Mutagenic Substances, Mixtures, Agents or Technological Processes [61], the number of enterprises in Poland, where the exposure to cytostatics occurred and employees were exposed to cytostatics, increased. However, due to the legal changes described above, the information collected in the register is still incomplete.

Moreover, without legally binding OELs, it is difficult to conduct the proper occupational exposure and risk assessment of active compounds of cytostatics, and the cytostatics airborne and biological concentration monitoring methods should be prepared by the employer. That is why setting the binding OELVs of cytostatics seems to be important, given especially that the recent technological progress in analytic methodology of measuring chemical substances by means of various media enables reliable measurements of very low concentrations. In 2015-2016 the Polish GECA, acting within the framework of the Interdepartmental Commission for Maximum Admissible Concentrations and 
Intensities for Agents Harmful to Health in the Working Environment, using health based criteria, recommended OELVs for 4 cytostatics - methotrexate, cyclophosphamide, cisplatin and hydroxyurea [69-72]. Currently, there is ongoing legislative work to introduce the proposed reference values (OELVs) to the Polish list of legally binding OELs. Concurrently, the selective analytical methods of determining these cytostatics at the workplaces were developed within the works of GECA. Legal provisions governing the issues connected with biological monitoring, and especially with the use of cytogenetic methods among healthcare workers exposed to cytostatics, are still lacking while these seem to be the most appropriate methods of characterizing such exposure.

Regulations concerning the safety and health of workers occupationally exposed to cytostatics are not only ambiguous but also require amendments to be compliant with the continuously changing treatment and therapies standards, and with the newest scientific data concerning health effects of occupational exposure to these chemicals. In Poland the legal basis governing health and safety at work during the preparation, administration and storage of cytostatic drugs in healthcare facilities has not been amended for nearly 20 years.

To sum up:

- Cytostatics are chemical substances or their mixtures. They are subject not only to the provisions concerning medicinal products and devices, but also to the provisions regulating chemicals in the market (REACH and CLP). Employers' obligations concerning health protection of workers, resulting from these regulations, are strictly related to the classification of a cytostatic as a chemical substance.

- The key document including and forwarding the information on the chemical substances' classification in the supply chain is the safety data sheet. However, the SDS is not required for medicinal products which are in the finished state, despite the fact that, according to the toxicological data, they may be hazardous to human health or life of occupationally exposed workers. In the authors' opinion, the supplier of medicinal products in the finished state should be legally obliged to provide information on hazard classes and categories according to the CLP, at least for the substances or mixtures that meet the criteria for classification as carcinogenic or mutagenic.

- It seems reasonable and necessary to prepare legally binding solutions enabling the effective monitoring of occupational exposure to cytostatics, both by cytogenetic monitoring among workers and airborne concentrations measurements. The legally binding OELVs for cytostatics, or their active components, suitable for monitoring current working conditions in the healthcare sector should be set.

\section{REFERENCES}

1. Petit M, Curti C, Roche M, Montana M, Bornet C, Vanelle P. Environmental monitoring by surface sampling for cytotoxics: A review. Environ Monit Assess. 2017;189:52, https://doi. org/10.1007/s10661-016-5762-9.

2. Walusiak-Skorupa J, Wągrowska-Koski E, Pałczyński C. [Cytostatics, occupational exposure, health effects, prevention]. 3rd ed. Łódź: Instytut Medycyny Pracy; 2009. Polish.

3. Connor TH, McDiarmid MA. Preventing occupational exposures to antineoplastic drugs in health care settings. CA Cancer J Clin. 2006;56(6):354-65, https://doi.org/10.3322/canjclin. 56.6.354.

4. Villarini M, Gianfredi V, Levorato S, Vannini S, Salvatori T, Moretti M. Occupational exposure to cytostatic/antineoplastic drugs and cytogenetic damage measured using the lymphocyte cytokinesis-block micronucleus assay: A systematic review of the literature and meta-analysis. Mutat Res. 2016;770:35-45, https://doi.org/10.1016/j.mrrev.2016.05.001.

5. Sessink PJM, Friemel NSS, Anzion RBM, Bos RP. Biological and environmental monitoring of occupational exposure of pharmaceutical plant workers to methotrexate. Int Arch Occup Environ Health. 1994;65(6):401-3, https://doi. org/10.1007/BF00383251. 
6. Sorsa M, Pyy L, Salomaa S, Nylund L, Yager JW. Biological and environmental monitoring of occupational exposure in industry and hospitals. Mutat Res. 1988;204(3):465-79, https://doi.org/10.1016/0165-1218(88)90042-0.

7. Pośniak M, Bartoszko D. [Analysis and assessment of chemical hazards during drugs production] [Internet]. Warszawa: Centralny Instytut Ochrony Pracy - Państwowy Instytut Badawczy; 2009 [cited 2017 Jan 17]. Available from: https:// www.ciop.pl/CIOPPortalWAR/file/71289/farmacja_leki.pdf. Polish.

8. European Commission: Health and Consumers Directorate General. EudraLex. The rules governing medicinal products in the European Union. Volume 4. Good manufacturing practice. Medicinal products for human and veterinary use. Annex 11: Computerised Systems [Internet]. Brussels: 2010 [cited 2017 Jun 30]. Available from: http:// ec.europa.eu/health//sites/health/files/files/eudralex/vol-4/ annex11_01-2011_en.pdf.

9. Miśkiewicz A, Cywińska A, Winnicka A. [The problem of occupational exposure to cytostatics used in veterinary practice]. Zycie Wet. 2014;89(11):934-9. Polish.

10. Health and Safety Executive [Internet]. London: The Executive; c2017 [cited 2017 Jan 17]. Safe handling of cytotoxic drug in workplace. Available from: http://www.hse.gov.uk/ healthservices/safe-use-cytotoxic-drugs.htm.

11. Health and Safety Executive. Control of substances hazardous to health. The control of substances hazardous to health regulations 2002 (as amended) [Internet]. 6th ed. London: The Executive; 2013 [cited 2017 Jan 17]. Available from: http:/www.hse.gov.uk/pubns/priced/15.pdf.

12. United States Department of Labor [Internet]. Washington: Occupational Health and Safety Administration; 2017 [cited 2017 Jun 20]. Controlling occupational exposure to hazardous drugs. Available from: https://www.osha.gov/ SLTC/hazardousdrugs/controlling_occex_hazardousdrugs. html\#intro.

13. National Institute for Occupational Safety and Health (NIOSH). NIOSH Alert. Preventing occupational exposure to antineoplastic and other hazardous drugs in health care settings. DHHS (NIOSH) Publication No. 2004-165 [Internet]. Cincinnatti: The Institute; 2004 [cited 2017 Jun 20]. Available from: https:/www.cdc.gov/niosh/docs/2004-165/ pdfs/2004-165.pdf.

14. World Health Organization. Good practice in occupational health services: A contribution to workplace health [Internet] Geneva: The Organization; 2002 [cited 2017 Mar 30]. Available from: http://www.euro.who.int/_data/assets/pdf_ file/0007/115486/E77650.pdf.

15. American Society of Health-System Pharmacists. ASHP Guidelines on Handling Hazardous Drugs. Am J Health Syst Pharm. 2006;63:1172-93.

16. International Society of Oncology Pharmacy Practicioners Standards Committee. ISOPP Standards of Practice. Safe handling of cytotoxics. J Oncol Pharm Pract, 2007;13 Suppl:1-81.

17. Working Committee on the Safe Handling of Hazardous. Prevention guide. Safe handling of hazardous drugs [Internet]. Montreal: ASSTSAS; 2008 [citied 2017 Jan 17]. Available from: https://asstsas.qc.ca/sites/default/files/publications/documents/Guides_Broch_Depl/GP65A_hazardous_drugs.pdf.

18. Neuss MN, Polovich M, McNiff K, Esper P, Gilmore TR, LeFebvre KB, et al. 2013 Updated American Society of Clinical Oncology/Oncology Nursing Society Chemotherapy Administration Safety Standards for the safe administration and management of oral chemotherapy. Oncol Nurs Forum. 2013;40(3):225-233, https://doi.org/10.1188/13.ONF.40$03 \mathrm{AP} 2$.

19. Graeve CU, McGovern PM, Alexander B, Church T, Ryan A, Polovich M. Occupational exposure to antineoplastic agents. An analysis of health care workers and their environments. Workplace Health Saf. 2017;65(1):9-20, https://doi. org $/ 10.1177 / 2165079916662660$.

20. Preventing occupational exposure to cytotoxic and other hazardous drugs. European Policy Recommendations [Internet]. European Parliament; 2016 [cited 2017 Mar 30]. 
Available from: https://www.skipr.nl/wosmedia/7356/cytotoxische_geneesmiddelen.pdf.

21. Regulation (EC) No 1907/2006 of the European Parliament and of the Council of 18 December 2006 concerning the Registration, Evaluation, Authorisation and Restriction of Chemicals (REACH), establishing a European Chemicals Agency, amending Directive 1999/45/EC and repealing Council Regulation (EEC) No 793/93 and Commission Regulation (EC) No 1488/94 as well as Council Directive 76/769/EEC and Commission Directives 91/155/EEC, 93/67/EEC, 93/105/EC and 2000/21/EC. Off J Eur Union L L 396, p. 1 (Dec 30, 2006).

22. Regulation (EC) No 1272/2008 of the European Parliament and of the Council of 16 December 2008 on classification, labelling and packaging of substances and mixtures, amending and repealing Directives 67/548/EEC and 1999/45/EC, and amending Regulation (EC) No 1907/2006. Off J Eur Union L 353, p. 1-1355 (Dec 31, 2008).

23. Barton-Burke M, Wilkes GM. Cancer therapies. Sudbury: Jones and Bartlett Publishers; 2006.

24. Friese CR, McArdle C, Zhao T, Sun D, Spasojevic I, Polovich M, et al. Antineoplastic drug exposure in an ambulatory setting: A pilot study. Cancer Nurs. 2015;38(2):111-7, https://doi.org/10.1097/NCC.0000000000000143.

25. Kromhout H, Hoek F, Uitterhoeve R, Huijbers R, Overmars RF, Anzion R, et al. Postulating a dermal pathway for exposure to antineoplastic drugs among hospital workers. Applying a conceptual model to the three workplace surveys. Ann Occup Hyg. 2000;44(7):551-60, https://doi.org/10.1016/ S0003-4878(00)00050-8.

26. Jankowiak-Gracz H. Jakość i bezpieczeństwo w praktyce farmacji szpitalnej [Internet]. Proceedings of the 11th Forum of Clinical Hospitals; 2012 Nov 22-23; Poznań, Poland [cited 2017 Aug 30]. Available from: http://docplayer. pl/17272015-Jakosc-i-bezpieczenstwow-praktyce-farmacjiszpitalnej.html. Polish.

27. Meade E. Avoiding accidental exposure to intravenous cytotoxic drugs. Br J Nurs. 2014;23(16):34,36-39, https://doi. org/10.12968/bjon.2014.23.Sup16.S34.
28. Polovich M, Massoomi F, Power LA, Connor TH. Are gloves and gowns safe for handling chemotherapy? Pharm Purchasing Prod. 2015;12(1):2-4.

29. Polovich M. Minimizing occupational exposure to antineoplastic agents. J Infus Nurs. 2016;39(5):307-13, https://doi. org/10.1097/NAN.0000000000000183.

30. Sabatini L, Barbieri A, Lodi V, Violante FS. Biological monitoring of occupational exposure to antineoplastic drugs in hospital settings. Med Lav. 2012;103(5):394-401.

31. Sessink PJM, Kroese ED, van Kranen HJ. Cancer risk assessment for health care workers occupationally exposed to cyclophosphamide. Int Arch Occup Environ Health. 1995;67(5):317-23, https://doi.org/10.1007/BF00385647.

32. Walusiak J, Wągrowska-Koski E, Pałczyński C. [Health effects of occupational exposure to cytostatics in medical personnel in the light of compulsory prophylactics: A crosssectional study]. Med Pr. 2003;54(3):229-36. Polish.

33. Connor TH, Shults M, Fraser MP. Determination of the vaporisation of solutions of mutagenic antineoplastic agents at 23 and $37^{\circ} \mathrm{C}$ using a dessicator technique. Mut Res. 2000; 470(1):85-92, https://doi.org/10.1016/S1383-5718(00)00105-4.

34. Connor TH, Sessink P, Harrison BR, Pretty JR, Peters BG, Alfaro RM, et al. Surface contamination of chemotherapy drug vials and evaluation of new vial-cleaning techniques: Results of three studies. Am J Health Syst Pharm. 2005;62(5):475-84.

35. Hirst M, Mills DG, Tse S, Levin L, White DF. Occupational exposure to cyclophosphamide. Lancet. 1984;323(8370): 186-8, https://doi.org/10.1016/S0140-6736(84)92111-1.

36. Kiffmeyer TK, Kube C, Opiolka S, Schmidt KG, Schöppe G, Sessink PJM. Vapour pressures, evaporation behaviour and airborne concentrations of hazardous drugs: Implications for occupational safety. Pharm J. 2002;268:331-7.

37. Sessink PJ, Cerná M, Rössner P, Pastorková A, Bavarová H, Franková K, et al. Urinary cyclophosphamide excretion and chromosomal aberrations in peripheral blood lymphocytes after occupational exposure to antineoplastic agents. Mutat Res. 1994;309(2):193-9. 
38. De Werk Neal A, Wadden RA, Chiou WL. Exposure of hospital workers to airborne antineoplastic agents. Am J Hosp Pharm. 1983;40(4):597-601.

39. Meijster T, Fransman W, Veldhof R, Kromhout H. Exposure to antineoplastic drugs outside the hospital environment. Ann Occup Hyg. 2006;50(7):657-64, https://doi.org/10.1093/ annhyg/mel023.

40. Sessink PJ, Anzion RB, van den Broek PHH, Bos RB. Detection of contamination with antineoplastic agents in a hospital pharmacy department. Pharm Weekbl Sci. 1992;14(1):16-22.

41. Valanis BG, Vollmer WM, Labuhn KT, Glass AG. Association of antineoplastic drug handling with acute adverse effects in pharmacy personnel. Am J Hosp Pharm. 1993; 50(3):455-62.

42. Pucci E, Matozzo F, Luppi P, Micoli G, Sottani C, Minoia C. [Headache as a "sentinel" symptom in personnel involved in the preparation and administration of antineoplastic drugs]. G Ital Med Lav Ergon. 2005;27(4):412-6. Italian.

43. McDiarmid M, Egan T. Acute occupational exposure to antineoplastic agents. J Occup Med. 1988;30(12):984-7.

44. Krstev S, Perunicic B, Vidakovic A. Work practice and some adverse health effects in nurses handling antineoplastic drugs. Med Lav. 2003;94(5):432-9.

45. Sotaniemi EA, Sutinen S, Arranto AJ, Sutinen S, Sotaniemi KA, Lehtola J. Liver damage in nurses handling cytostatic agents. Acta Med Scand. 1983;214(3):181-9.

46. Cieślicka A, Gębka M, Rząca M, Kocka K, Pietraszek A, Bartoszek A, et al. [The health consequences of occupational exposure to cytostatics among nurses.] J Educ Health Sport. 2016;6(9):566-74, https://doi.org/10.5281/zenodo.154 995. Polish.

47. Kusnetz E, Condon M. Acute effects from occupational exposure to antineoplastic drugs in a para-professional health care worker. Am J Ind Med. 2003;44(1):107-9, https://doi. org/10.1002/ajim.10230.

48. Balcarová O, Zavázal V, Seberová E, Kuklová D, Halík J. The risk of work with cytostatics and immunomodulation compounds. Pracov Lék. 1993;45:195-201.
49. Fransman W, Vermeulen R, Kromhout H. Dermal exposure to cyclophosphamide in hospitals during preparation, nursing and cleaning activities. Int Arch Occup Environ Health. 2005;78(5): 403-12, https://doi.org/10.1007/s00420-004-0595-1.

50. Vyas N, Yiannakis D, Turner A, Sewell GJ. Occupational exposure to anti-cancer drugs: A review of effects of new technology. J Oncol Pharm Pract. 2014;20(4):278-87, https:// doi.org/10.1177/1078155213498630.

51. Rekhadevi PV, Sailaja N, Chandrasekhar M, Mahboob M, Rahman MF, Grover P. Genotoxicity assessment in oncology nurses handling anti-neoplastic drugs. Mutagenesis. 2007;22(6):395-401, https://doi.org/10.1093/mutage/gem032. 52. Cavallo D, Ursini CL, Perniconi B, Francesco AD, Giglio M, Rubino FM, et al. Evaluation of genotoxic effects induced by exposure to antineoplastic drugs in lymphocytes and exfoliated buccal cells of oncology nurses and pharmacy employees. Mutat Res. 2005(1-2);587:45-51, https://doi.org/ 10.1016/j.mrgentox.2005.07.008.

53. Burgaz S, Karahalil B, Canh Z, Ancel G, Anzion RBM, Bos RP, et al. Assessment of genotoxic damage in nurses occupationally exposed to antineoplastics by the analysis of chromosomal aberrations. Hum Exp Toxicol. 2002;21(3): 129-35, https://doi.org/10.1191/0960327102ht230oa.

54. Santovito A, Cervella P, Delpero M. Chromosomal damage in peripheral blood lymphocytes from nurses occupationally exposed to chemicals. Hum Exp Toxicol. 2014;33(9):897903, https://doi.org/10.1177/0960327113512338.

55. McDiarmid MA, Rogers B, Oliver M. Chromosomal effects of non-alkylating drug exposure in oncology personnel. Environ Mol Mutagen. 2014;21:55(4):369-74, https://doi.org/ 10.1002/em.21852.

56. Connor TH, Lawson CC, Polovich M, McDiarmid MA. Reproductive health risks associated with occupational exposures to antineoplastic drugs in health care settings: A review of the evidence. J Occup Environ Med. 2014;56(9):901-10, https://doi.org/10.1097/JOM.0000000000000249.

57. Lawson CC, Rocheleau CM, Whelan EA, Lividoti Hibert EN, Grajewski B, Spiegelman D, et al. Occupational 
exposures among nurses and risk of spontaneous abortion. Am J Obstet Gynecol. 2012;206(4):327.e1-8, https://doi. org/10.1016/j.ajog.2011.12.030.

58. Szmyd K, Haus O. [Cancers among medical personnel exposed to anticancer agents]. Med Pr. 2011;62(1):17-21. Polish.

59. [Regulation of the Minister of Health of 24 July 2012 on substances, preparations and factors or technological processes with carcinogenic or mutagenic effect in work environment. J Laws 2012, item 890]. Polish.

60. International Agency for Research on Cancer [Internet]. Pharmaceuticals. Volume 100A. A review of human carcinogens. IARC monographs on the evaluation of carcinogenic risks to humans. Lyon: The Agency; 2012. [cited 2017 Jul 15]. Available from: https:/monographs.iarc.fr/wp-content/uploads/2018/06/mono100A.pdf

61. [Central Register of Data on Exposure to Carcinogenic or Mutagenic Substances, Mixtures, Agents or Technological Processes (unpublished materials)]. Łódź: Nofer Institute of Occupational Medicine; 2016. Polish.

62. Polish State Sanitary Inspection. [Report on activities taken in 2010 in occupational hygiene] (unpublished materials). Warszawa: The Inspection; 2011. Polish.

63. Council Directive 89/391/EEC of 12 June 1989 on the introduction of measures to encourage improvements in the safety and health of workers at work. Off J Eur Union L 183, p. 1-8 (Jun 29, 1989).

64. Council Directive 98/24/EC of 7 April 1998 on the protection of the health and safety of workers from the risks related to chemical agents at work (fourteenth individual Directive within the meaning of Article 16(1) of Directive 89/391/ EEC). Off J Eur Union L 131, p. 11-23 (May 5, 1998).

65. Directive 2004/37/EC of the European Parliament and of the Council of 29 April 2004 on the protection of workers from the risks related to exposure to carcinogens or mutagens at work (Sixth individual Directive within the meaning of Article 16(1) of Council Directive 89/391/EEC) (codified version). Off J Eur Union L 158, p. 50-76 (Apr 30, 2004).
66. Directive 2001/83/EC of the European Parliament and of the Council of 6 November 2001 on the Community code relating to medicinal products for human use. Off J Eur Union L 311, p. 0067-128 (Nov 28, 2001).

67. European Chemicals Agency [Internet]. Helsinki: The Agency; 2017 [cited 2017 Jan 19]. Will medicinal products need to be classified and notified to the Classification and Labelling Inventory? Q\&As, CLP, ID 0178 (2015 Jun 4). Available from: https://echa.europa.eu/pl/support/qas-support/qas/-/qand-a/7d0d0af6-aa94-417f-a093-d4714f5440dc?/.

68. World Health Organization [Internet]. Geneva: The Organization; 2017 [cited 2017 Jun 20]. Guidelines on the implementation of the WHO certification scheme on the quality of pharmaceutical products moving in international commerce. Available from: http://www.who.int/medicines/areas/quality_ safety/regulation_legislation/certification/guidelines/en/.

69. Hedmer M. Monitoring of occupational exposure to antineoplastic drugs [doctoral dissertation]. Lund: Lund University; 2006 [cited 2017 Jun 20]. Available from: http://portal. research.lu.se/portal/files/4525228/546645.pdf.

70. Centers for Disease Control and Prevention [Internet]. NIOSH list of antineoplastic and other hazardous drugs in healthcare settings, 2016. Atlanta: U.S. Department of Health and Human Services; 2017 [cited 2017 Jan 17]. Available from: https://www.cdc.gov/niosh/docs/2016-161/.

71. [Regulation of the Minister of Health of 2 February 2011 on tests and measurements of factors harmful to health in the working environment. J Laws 2011, No. 33, item 166]. Polish.

72. Szewczyńska M, Pośniak M, Krzemińska S. [Cisplatin. Determination in workplace air with high performance liquid chromatography]. PiMOSP. 2016;1(87):47-64. Polish.

73. Brzeźnicki S, Bonczarowska M, Mikołajewska K. [Methotrexate. Determination method in workplace air]. PiMOSP. 2015;1(87):93-108, https://doi.org/10.5604/1231868X.1200150. Polish.

74. Brzeźnicki S, Bonczarowska M. [Cyclophoshamide. Determination method in workplace air (unpublished material)]. 2016. Polish. 
75. Szewczyńska M, Osytek A, Pośniak M, Galwas-Grzeszkiewicz M. [N-Hydroxyurea - Determination method]. Podst Met Oceny Srod Prac. 2010;1(63):155-62. Polish.

76. Kupczewska-Dobecka M. [Methotrexate. Documentation of the proposed occupational exposure limit values]. Podst Met Oceny Srod Prac. 2015;1(83):73-118. Polish.

77. Gromiec J. [Cyclophosphamide. Documentation of the proposed occupational exposure limit values]. Podst Met Oceny Srod Prac. 2015;1(83):17-71. Polish.
78. Pałaszewska-Tkacz A, Świdwińska-Gajewska A, Czerczak S. [Cisplatin. Documentation of the proposed occupational exposure limit values]. Podst Met Oceny Srod Prac. 2018;1(95): 73-118. Polish.

79. Kupczewska-Dobecka M. [N-Hydroxycarbamide - inhalable fraction. Documentation of the proposed occupational exposure limit values]. Podst Met Oceny Srod Prac 2017;4(94):55-87. Polish.

This work is available in Open Access model and licensed under a Creative Commons Attribution-NonCommercial 3.0 Poland License - http://creativecommons.org/ licenses/by-nc/3.0/pl/deed.en. 